\title{
MYCOFLORA OF GRAIN MAIZE (Zea mays L.) STORED IN \\ TRADITIONAL STORAGE CONTAINERS (GOMBISA AND SACKS) IN \\ SELECTED WOREDAS OF JIMMA ZONE, ETHIOPIA
}

\section{Dubale $B^{1}$, Solomon $A^{2}$, Geremew $B^{3}$, Sethumadhava Rao $G^{* 4}$ and Waktole $S^{4}$}

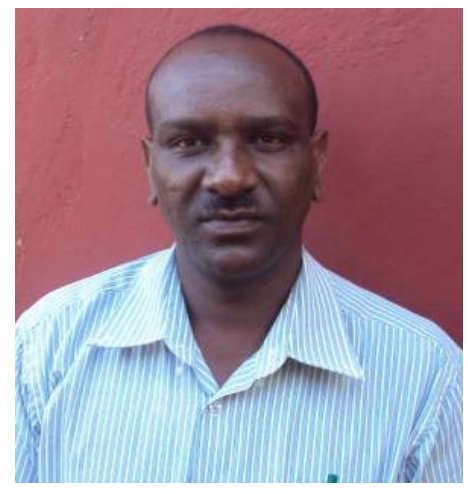

Dubale Befekadu

*Corresponding author’s email: g_sethu2868@yahoo.co.in

${ }^{1}$ Jimma Agricultural Mechanization Research Center; Jimma, Ethiopia

${ }^{2}$ School of Natural Resource and Environmental Engineering, Haramaya University, Ethiopia

${ }^{3}$ Department of Food Science and Postharvest Technology, Haramaya University, Ethiopia

${ }^{4}$ Jimma University College of Agriculture and Veterinary Medicine, Jimma, Ethiopia. 


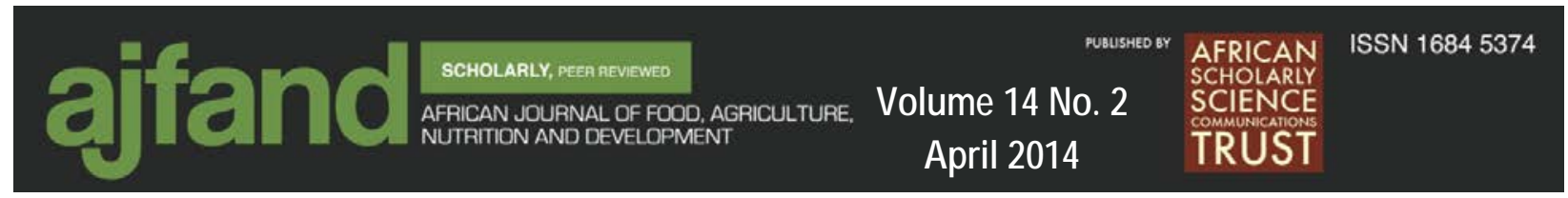

\begin{abstract}
Mycoflora of maize (Zea mays L.) grain (Variety: Bako Hybrid-660) stored in two traditional storage containers (Gombisa and Sacks) for 180 days was studied for mycoflora in two agro-ecologies, that is Intermediate and Lowland, with altitude ranges of 1500-2500 meters above sea level, and 1000-1500 meters above sea level, respectively, in Jimma zone, Ethiopia. The temperature and relative humidity were observed for identifying fungi species which can flourish and cause maximum deterioration to maize grains. Significant $(P<0.05)$ decreases in germination rate of the grains were observed with time under each storage method for both the low and intermediate altitude ranges. Germination percentage reduced from $98 \%$ and $97.5 \%$ to 68.5\% and $80.5 \%$ for grains stored in Gombisa and Sacks, respectively. Storage type significantly $(\mathrm{p}<0.05)$ affected seed germination under intermediate agro-ecology whereas no significant ( $>0.05$ ) effect was observed under lowland agro-ecology due to storage container type. One sterile white mycelium and a total number of eight species of fungi viz., Aspergillus flavus, Aspergillus fumigatus, Aspergillus niger, Aspergillus tereus, Cladosporium cladosporioides, Drechslera halodes, Fusarium oxysporum and Penicillium chrysogenum were identified from maize grain at the beginning and during storage. The most common fungi recorded from both agroecologies in the two storage structures were A. flavus, A. niger, D. halodes and F. oxysporum. These fungi were recorded from 90, 51, 72 and 44 percentage of the seed samples, respectively. In the districts of both intermediate and lowland agro-ecology these fungi were consistently recorded throughout 180 days, during storage. A. fumigatus was detected in $3.6 \%$ of samples while C. cladosporioides observed in $15 \%$ of the samples. Fungal species A. tereus and Penicillium were recorded in $0.5 \%$ of samples in selected districts of Jimma. These fungal species were known to cause deterioration of maize and are a health risk to humans and animals due to the toxins they potentially produce.
\end{abstract}

Key words: Agro ecologies, Fungi, Maize, Storage 


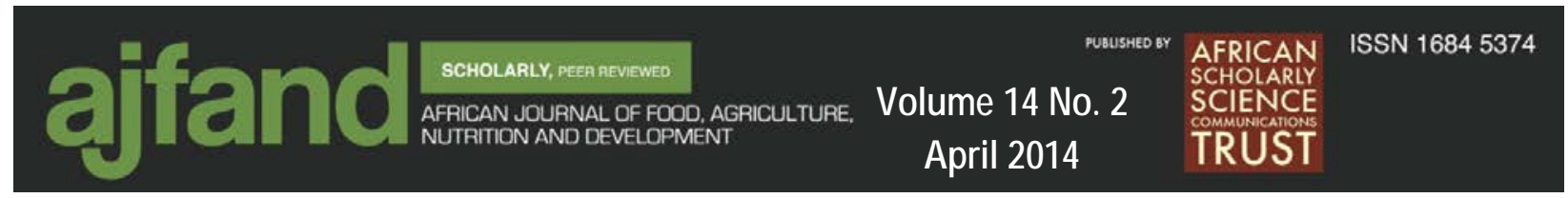

\section{INTRODUCTION}

In Ethiopia, maize (Zea mays L.) is a staple food and one of the main sources of calories in the major producing areas [1]. The crop ranks first in total production area and yield per hectare [2]. Maize has been selected as one of the national commodity crops to satisfy the food self-sufficiency program of the country to feed the alarmingly increasing population [1]. However, the grain undergoes quantitative and qualitative losses during storage. The losses occur mainly because of improper storage [3]. A large number of pathogenic fungi, bacteria, viruses and insects infecting and infesting maize grain cause combined worldwide annual losses of 9.4\% [4]. Fungi affect the quality of grain as a result there will be, increase in fatty acid, reduction in germination, increase its mustiness, production of toxins and finally leading to spoilage of grain in many ways.

Fungi are the second important cause of deterioration and loss of maize next to insects [5, 6]. Fungi could cause about 50 to $80 \%$ of damage on farmers' maize during storage if conditions are favorable for their development [5]. The major genera commonly encountered on maize in tropical regions are Aspergillus, Fusarium and Penicillium [7, 8]. This is the cause of concern because these genera have species capable of producing a wide spectrum of compounds shown to be toxic to man and animals [9-15].

A survey conducted in three major maize grain producing areas of Ethiopia indicated that the majority of farmers (93.3\%) use traditional storage containers that expose their stored grains to attack by storage pests and/or other factors. The average actual loss per household was about 12 percent of the average total grain produce [16]. Since deterioration of stored grains results from the interactions of pathogens, physical factors and storage containers it is important to understand the inter-relations and interactions of these variables in order to design effective control and management of these factors for safe grain storage [17]. Grain storage containers being used by majority of farmers in Jimma zone (more than 97\%) are traditional ones that couldn't protect the stored grain from deterioration [18]. There is no information on the exact cause of deterioration of grains stored in these traditional storages in the zone that could serve as basis to take corrective measures. Availability of such information will help to take corrective measures in improving post harvest grain management and hence support the efforts being made to become a food secured country. The patterns of storage temperature, relative humidity and the associated fungi of maize stored in the traditional storage containers in the area are not clearly known and documented. It is, therefore, essential to study the existing fungal species that infect grains of maize stored in two major traditional storage containers (Gombisa and Sacks) and the influence of altitude/elevation (both intermediate and lowland ago-ecologies) on fungal infection of stored maize grain over time under traditional storage facilities. 


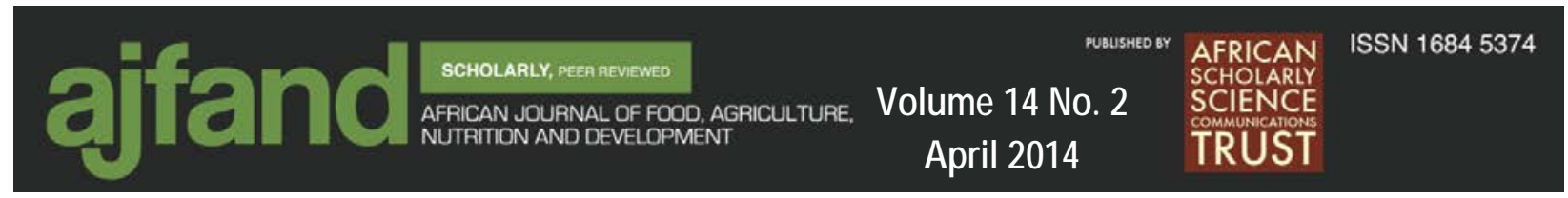

\section{MATERIALS AND METHODS}

\section{Description of the study area}

The study was carried out in Jimma zone, Ethiopia which is found at about $345 \mathrm{~km}$ from Addis Ababa in South west and lies between $36^{\circ} 10^{\prime} \mathrm{E}$ longitude and $7^{\circ} 40^{\prime} \mathrm{N}$ latitude. The zone has an elevation ranging from 880 to 3360 meters above sea level (masl). The area experiences annual average rainfall of $1000 \mathrm{~mm}$ for 8 to 10 months. The main rainy season extends from May to September and the small rainy season takes place in February, March and April. The temperature of Jimma zone varies from $8-28^{\circ} \mathrm{C}$. The average annual temperature is $20^{\circ} \mathrm{C}$ [19].

The agro-ecologies of the study area have an altitude range of 1000-1500 (lowlands), 1500-2500 (intermediate) and 2500-3360 masl (highlands) [20]. Only two agroecologies (intermediate and lowlands) growing $\mathrm{BH}-660$ maize variety were selected for the study since BH-660 maize variety is currently not produced in the highland agro-ecology of the study area. Districts that exhibit wide production of BH-660 maize variety in the study area were selected, Omo Nada and Kersa from intermediate agro-ecology and Tiro Afeta and Sekoru from the lowland agro-ecology.

\section{Experimental design and treatments}

Factorial arrangement using Completely Randomized Design (CRD) was employed for the experiment in two replications. There were three factors: traditional maize storage containers at two levels (Gombisa and Sack), agro-ecologies at two levels (lowland and intermediate), and storage periods at four levels (initial, 60, 120 and 180 days after harvest). The study was conducted for six months in 2009/2010 harvesting season by taking samples at two months interval. Baseline data was collected at the start of the study period for comparison. A total of 96 samples (12 samples per treatment) were taken during six months of the storage period.

\section{Experimental materials}

The experimental materials used for the study were BH-660 variety of maize grain harvested in December 2009 and two types of traditional maize storage containers (Gombisa and Sacks).

Gombisa is an above ground cylindrical shaped traditional storage bin used to store maize cob. It is vertical un-plastered wall made from woven plant stems usually Eucalyptus. Conical grass- thatched roofing is used to cover the top end, usually overhanging it about $70 \mathrm{~cm}$ out of the wall. The structure rests on a low level (10 to $60 \mathrm{~cm}$ ) wooden platform mounted on four, six or eight stone pillars or on a short yoked wooden post $(10$ to $60 \mathrm{~cm})$ firmly driven in to the ground (penetrating the ground). The floor is made of mats of woven bamboo splits and dry stalks of sorghum under which a wooden beam of Eucalyptus laid. The floor is usually plastered with salt and cow dung mixture (1.5 kg table salt per $\mathrm{kg}$ cow dung and a liter of water). The height of Gombisa ranged from 124 to $155 \mathrm{~cm}$ while its diameter varies from 148 to $304 \mathrm{~cm}$. consequently the capacity varies from 10 to 25 Quintals of maize cobs. It 


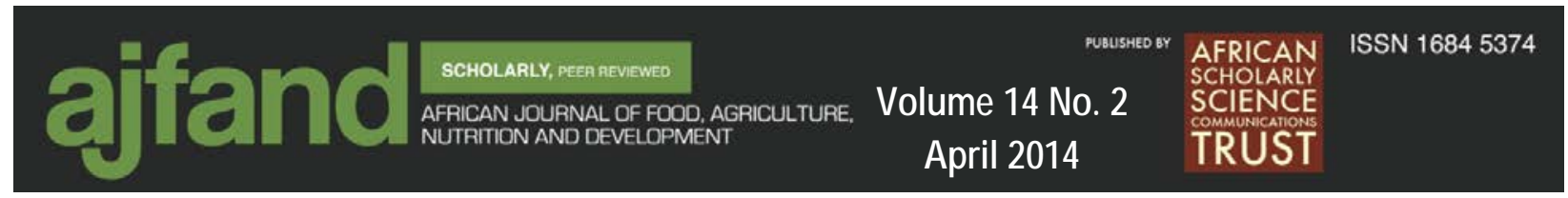

is generally neither air tight nor moisture and insect proof. Maize cob loading and unloading are effected by removing the thatched roofing.

A polypropylene Sack is the other type of storage container to store shelled maize after treating it with either of traditional or modern pesticides. It is made of woven synthetic fiber and low cost indoor storage container that can hold 50 to $100 \mathrm{~kg}$ of shelled maize grain which is a readily available. Rodents are known to dislike nibbling polypropylene Sacks, as the strands tend to get in between their teeth (21). It cannot be used for storing maize for long term storage (more than 6 months) because the material tends to inhibit free circulation of air with in the Sack. Polypropylene Sack is also difficult to fumigate. It is puncture resistant and has moderate permeability to moisture, gases and odors (21).

\section{Sampling of the Grain for Evaluation}

Cob samples in Gombisa were placed in three meshed wire cages that can hold about 10 cobs each. The cages were placed at the bottom end of $11 \mathrm{~cm}$ diameter polyvinyl chloride (PVC) tube the surface of which is perforated with $1.4 \mathrm{~cm}$ diameter so that the environment in the cage and the PVC tube is identical to that in the rest of the Gombisa. The cobs placed in the cages were each attached to a string the other end of which appears at the top of the stored grain. This arrangement is to facilitate removal of the sample cobs for analysis during the storage period. Three such cages connected to PVC tubes were placed at the center and the two sides of the middle layer in each Gombisa filled with maize cobs. They serve as representative samples of the stored maize cobs for evaluation throughout the study period.

Initial samples of six cobs were randomly taken before the bulk was loaded in to Gombisa, shelled manually to make $1 \mathrm{~kg}$ and then kept in an air-tight plastic bag. The initial maize samples from each storage containers were taken as a control at the beginning of the storage period. Subsequent sampling from Gombisa and Sacks was carried out at an interval of two months for the storage period of six months. Three cobs were drawn from each cage via the tube using strings, shelled manually and thoroughly mixed. For sampling grain from the Sacks, the procedure described in AOAC (1995) was followed [22].

\section{Physical Variables \\ Grain moisture content}

The grain moisture content was measured using a calibrated moisture tester (Dickeyjohn Corp. Auburn, IL 62615 USA) immediately before storage and during the subsequent grain sampling periods from each storage container.

\section{Storage temperature and relative humidity}

The storage temperature and relative humidity were measured at an interval of 15 days during the storage periods using portable digital Thermo- Hygrometer (Hanna, HI8564, Italy) [23]. 


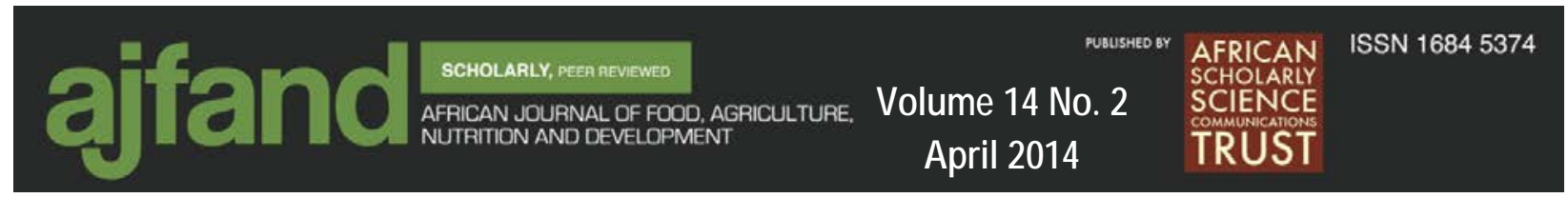

\section{Seed germination test}

Seed germination test was conducted using standard procedures of ISTA (1996) [24].

\section{Identification of fungi}

A total of sixty maize seeds were randomly taken from each sealed plastic bags. Half of the seeds (30) were surface sterilized with $1 \%$ sodium hypochlorite $(\mathrm{NaOCl})$ and the remaining (30 seeds) unsterilized. The surface treated and untreated seeds were plated on Potato Dextrose Agar (PDA), 10 seeds per Petri-plate and the petri-plates were incubated at $24{ }^{\circ} \mathrm{C}$ in alternating cycle of 12 hours light and 12 hours darkness for 7 days. The samples were incubated for additional 5 to 7 days to detect late appearing and slow sporulating fungi. Mounts from each fungal colony were prepared on a microscopic slide and then it was examined under high power magnification of a compound microscope. Fungi growing on seeds were identified up to species level by following standard manuals [3, 25 - 27]. The appearance of mycoflora and percentage occurrence of seed borne fungi detected from a total of 96 maize samples collected from four districts. The percentage of occurrence of fungi was calculated using the formula [22].

occurrence of fungi $(\%)=\frac{\text { Number of seeds in which a particular fungus occurred }}{\text { total seed incubated }} \times 100$

\section{Method of data analysis}

Statistical analysis was performed on response variables collected over the storage periods using ANOVA (Analysis of Variance) of SPSS (Statistical Package for the Social Sciences) Version 16.0. Means were compared for the significant factors by LSD (Least Significant Difference) test, and significance was accepted at 5\%. Descriptive statistics was also used for organizing and presenting the data of the identified fungi.

\section{RESULTS}

\section{Physical Quality Characteristics \\ Moisture content}

At the beginning of the storage in the intermediate agro-ecology the average moisture content of the grain was $13.23 \%$ and $13.50 \%$ for the cobs in Gombisa and shelled maize grains in Sacks, respectively. The study, however, showed that, in the lowland agro-ecology, the average moisture content of the grain with the cob (Gombisa) and shelled grain (Sacks) was $14.58 \%$ and $13.58 \%$, respectively (Figure 1). The average moisture content of maize just after harvest before storage was $13.37 \pm 0.41$ in intermediate and $14.08 \pm 0.33$ in lowland agro-ecologies. Grains stored in both storage containers lost moisture as storage time increased to 60 days reaching values of $10.07 \%$ and $10.57 \%$ in Gombisa and Sack, respectively under intermediate agroecology. In the following storage days, grain with the cob stored in Gombisa continued to lose moisture attaining the lowest value of about $9.17 \%$ after 180 days. The situation with shelled grains stored in the Sacks was different in that the moisture 


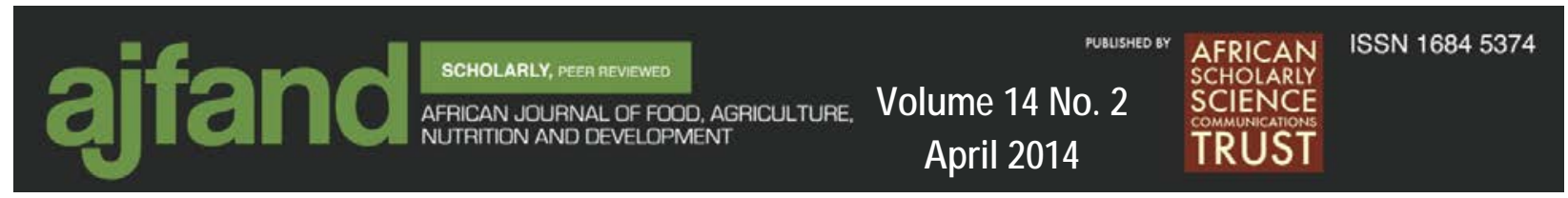

content exhibited increment to $11.08 \%$ at 120 days and $11.70 \%$ at 180 days of storage time. The grain moisture content recorded (Figure 1) both in Gombisa (14.58\%) and sack (13.58\%) under lowland agro-ecology during the initial loading day was found to be above the maximum safe moisture content (13.5\%) for storing maize grain. This moisture content of maize grain is favorable for growth/ survival and multiplication of the fungal species identified in the study during180 days of storage time. However, grain moisture content recorded in Gombisa (13.23\%) and sack (13.50\%) under intermediate agro-ecology is within the safe storage moisture content limit.

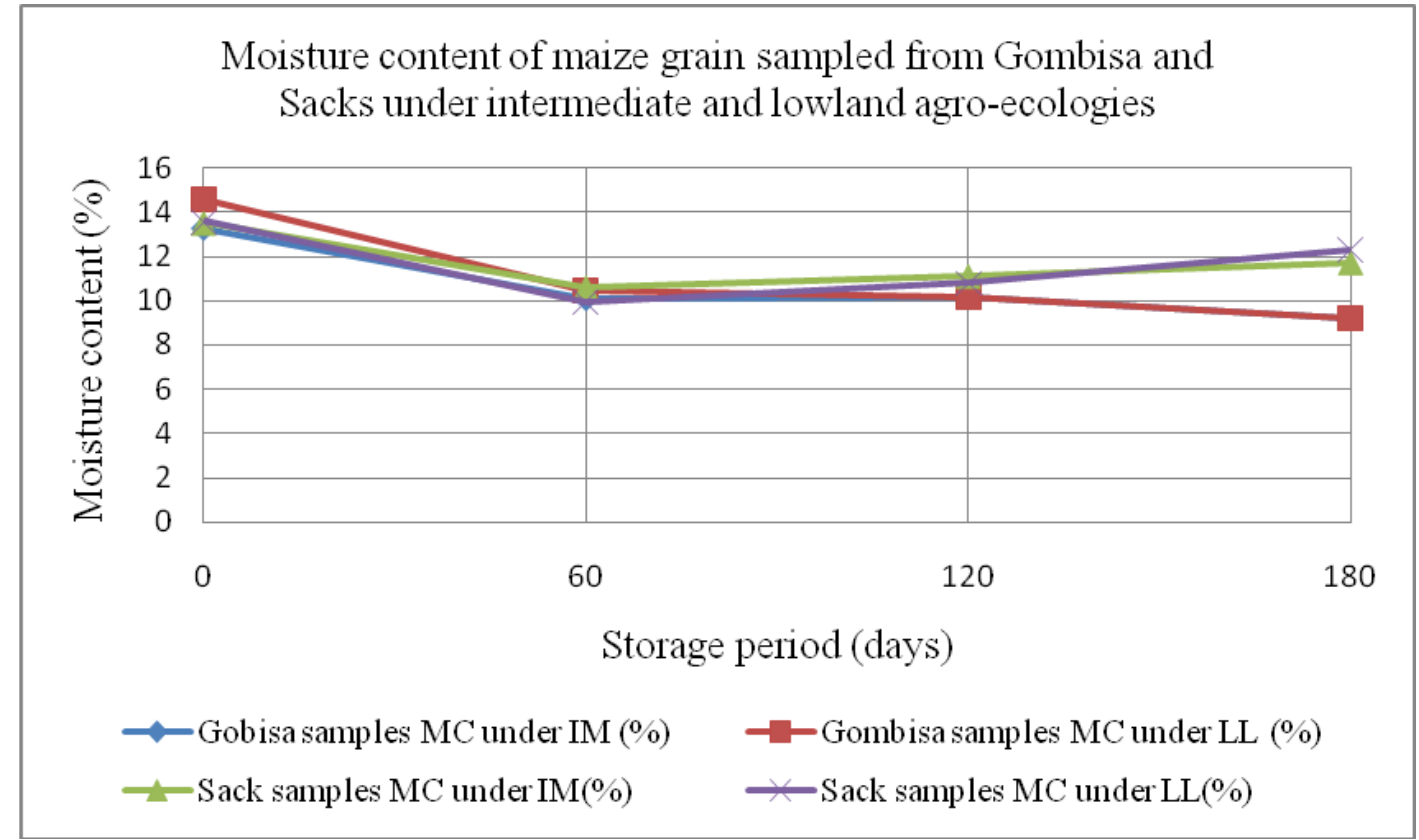

Figure 1: Moisture content (MC) of maize grain sampled from Gombisa and Sacks under intermediate (IM) and lowland (LL) agro-ecologies over storage periods of 180 days

\section{Storage temperature and relative humidity}

It is noted from Figures 2 and 3 that the average temperature had ranged from 18.50 to $30.00^{\circ} \mathrm{C}$ and 15.00 to $28.82{ }^{\circ} \mathrm{C}$ for Gombisa and Sack respectively under intermediate agro-ecology, while a temperature range of 21.30 to $35.00^{\circ} \mathrm{C}$ for Gombisa and 16.55 to $28.95^{\circ} \mathrm{C}$ for Sack were recorded with reference to lowland agro-ecologies. It is interesting to note that the average relative humidity under intermediate agro-ecology had ranged from 30.83 to $54.67 \%$ and 30.00 to $65.17 \%$ for Gombisa and Sack, respectively (Figure 2). Whereas the relative humidity ranges were 39.17 to $51.00 \%$ for Gombisa and 32.00 to $62.33 \%$ for Sack under lowland agroecology (Figure 3). These temperature and relative humidity records were optimal for the identified fungi species to flourish. 

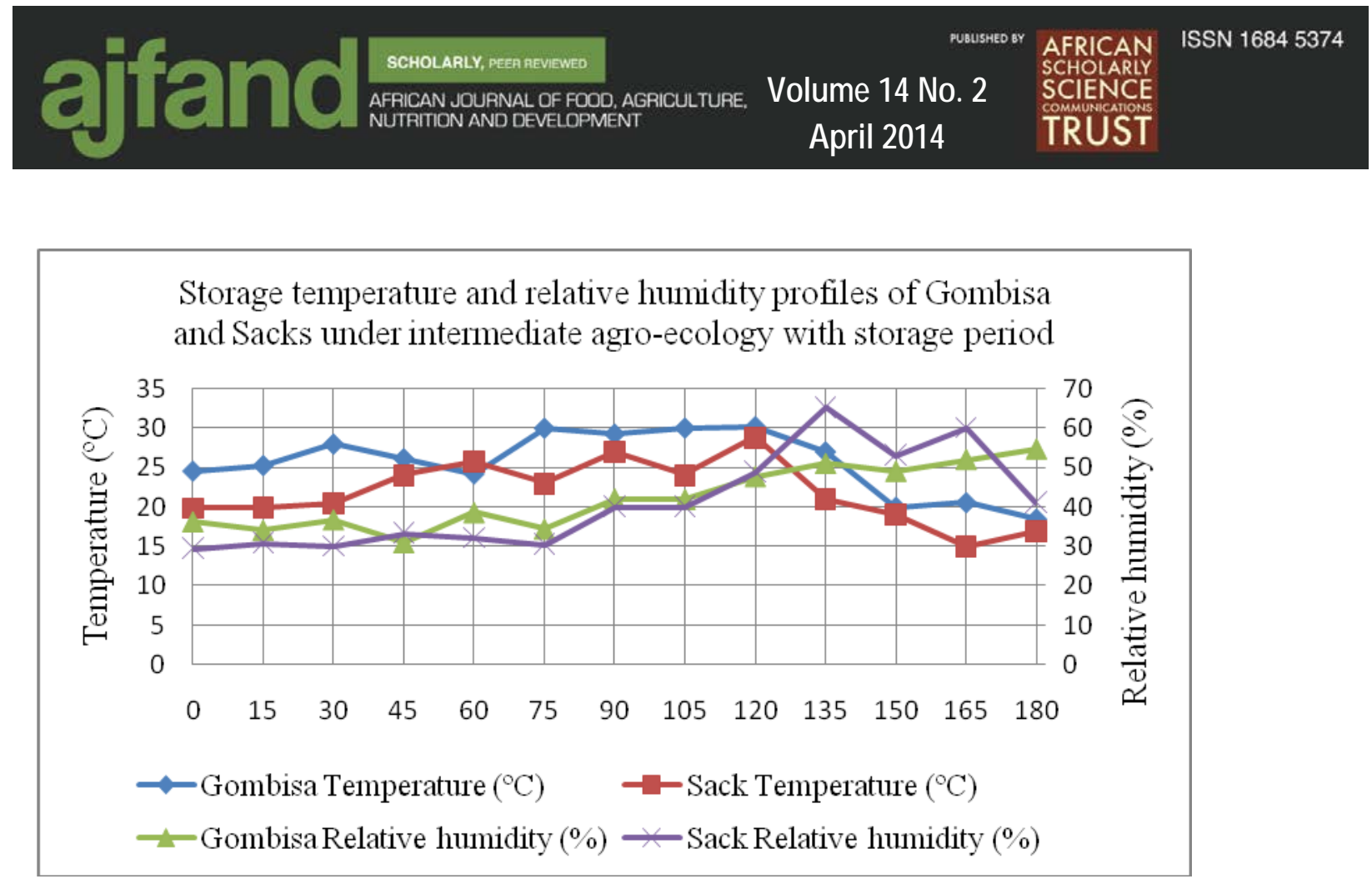

Figure 2: Storage temperature $\left({ }^{\circ} \mathrm{C}\right)$ and relative humidity $(\%)$ profiles of Gombisa and Sacks under intermediate agro-ecology over storage periods of 180 days

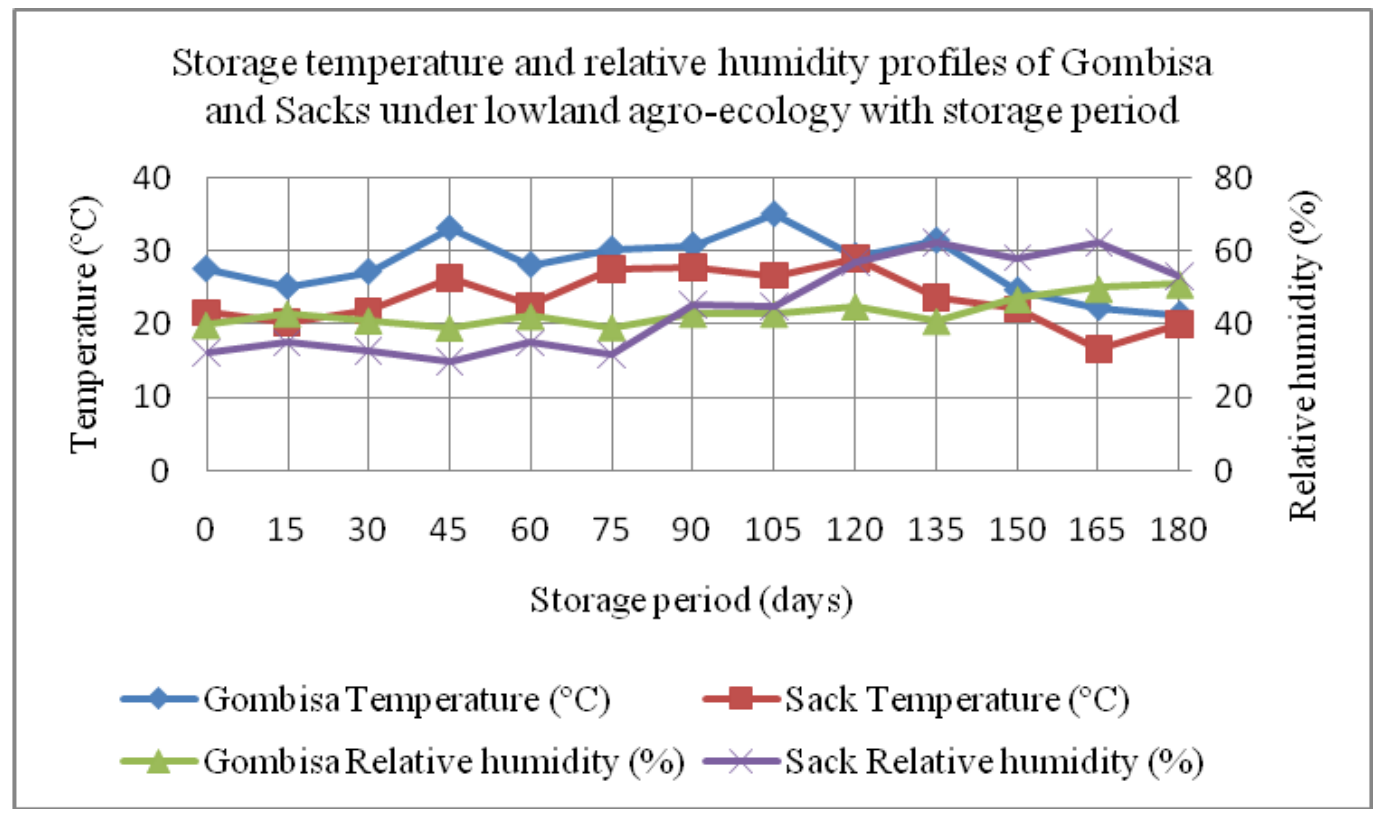

Figure 3: Storage temperature $\left({ }^{\circ} \mathrm{C}\right)$ and relative humidity $(\%)$ profiles of Gombisa and Sacks under lowland agro-ecology with storage period 


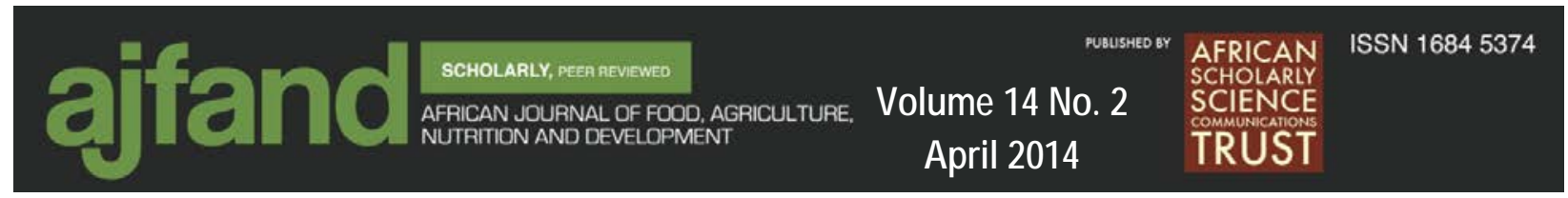

\section{Effects of storage periods on viability of maize grain under intermediate and lowland agro-ecologies}

The initial test for germination percentage under intermediate agro-ecology indicated $98 \%$ and $97.50 \%$ for Gombisa and Sacks, respectively (Table 1). However, the values exhibited statistically significant $(\mathrm{P}<0.05)$ reduction as the storage period increased. After two months, it dropped to $87.5 \%$ for kernels collected from Gombisa while it was $92.0 \%$ in Sacks. There was a significant $(\mathrm{P}<0.05)$ reduction in germination percentage reaching $\mathbf{8 0 . 1 7 \%}$ for grains collected from Sacks 120 days after storage. The germination capacity of kernels obtained from Gombisa further plunged to $68.50 \%$ in six months, while that of the kernels stored in the Sack dropped up to 120days.

Under lowland agro-ecologies $97.50 \%$ and 96.50 percentage of germination for Gombisa and Sacks respectively, was recorded during initial loading day. It was also noted that the values exhibited statistically significant $(\mathrm{P}<0.05)$ reduction as storage period increased to two months at which it dropped to $79.50 \%$ for kernels collected from Gombisa and $86.00 \%$ for kernels collected from Sacks. The results cited in Table 1 revealed that the values remain unchanged for the subsequent four and six months in both storage containers with final values of $70.17 \%$ and $83.83 \%$ in Gombisa and Sacks, respectively.

\section{Identification of fungi}

The observations in relation to fungal identification in the seeds of maize are given in Tables 2 and 3. All together eight species of fungi and one sterile white mycelium were isolated from maize seeds. These include Aspergillus flavus Link ex Grey, Aspergillus fumigatus Fres., Aspergillus niger Van Tieghem., Aspergillus terreus, Cladosporium cladosporioides (Fres) de Vries, Drechslera halodes Subram \& Jain., Fusarium oxysporum Schlecht., Emend. Synd \& Hans. and Penicillium chrysogenum Thom and (Wehmer) Westling.

The most common fungi isolated from grains stored in both storage containers (Gombisa and Sack) were A. flavus, A. niger, D. halodes and F. oxysporum in Kersa and Omo Nada of intermediate agro-ecology and in Sekoru and Tiro Afeta of lowland agro-ecology.

The results indicated that in almost all of the four districts these fungi were consistently recorded throughout 180 days of the storage period (Tables 2 and 3). In all of the studied districts, the presence of $A$. fumigatus, $C$. cladosporioides, $A$. terreus and Penicillium spp. were inconsistent with the increase in the storage days. During the course of the present study, the species $P$. chrysogenum and A. terreus were detected in districts found under intermediate agro-ecology and they were detected only from maize samples stored in Gombisa from Kersa and Omo Nada, respectively (Table 2).

It is also evident from the data in Table 4, that A. flavus, A. niger, D. halodes, and F. oxysporum were the most frequent species of fungi recorded over the storage periods 


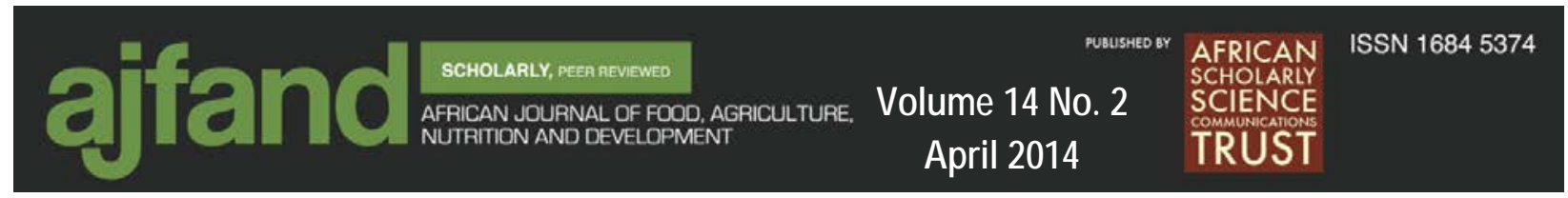

from $90 \%, 51 \%, 72 \%$ and $44 \%$ of the seed samples respectively, whereas $A$. fumigatus and $C$. cladosporioides were detected from 3.6 and $15 \%$ samples, respectively. Both A. terreus and Penicillium species were the most dominant species of fungi being detected only from $0.5 \%$ of the samples and sterile white mycelium was detected from $10 \%$ of seed samples.

\section{DISCUSSION}

It is clear from the results (Figure 1) that the differences in the initial grain moisture content of grains could be due to initial exposure of sampled grains to different ambient temperature and relative humidity. The loss of moisture after 180 days is probably due to the poor level of natural aeration in the grain stored in Sacks as compared to that in Gombisa along with the cumulative effect of respiration from the grain itself, insects and the mold population, which existed [28]. Further, polypropylene sack is moderately permeable to moisture, gases and odors [29]. The decrease in the moisture content from grains both in Gombisa and Sacks could be due to release of moisture in to the surrounding dry air. Interestingly, the decrease in the moisture content in Gombisa was higher than that in Sacks. This might be due to more ventilating capacity of the perforated wall of Gombisa than that of the Sack. In terms of moisture content the same trend was observed in both storage structures under lowland agro-ecology.

It was observed from the results (Figures $2 \& 3$ ) that the storage temperature and relative humidity recorded were optimal for the identified fungi species to flourish and cause maximum deterioration to maize grains.

It is evident from Table 1, that during the storage period, a gradual reduction in germination percentage of maize grain occurred for Gombisa under intermediate agroecologies, while the percentage was, relatively less, in case of Sacks. Germination loss in Gombisa and Sacks as the period of storage increased might be due to fungal invasion [30].

From Tables 2 and 3, it is concluded that, the most common fungi such as A. flavus, $A$. niger, $D$. halodes and $F$. oxysporum recorded in almost all the four districts throughout 6 months of storage period. While Cladosporium cladosporioides found upto 2 months for Gombisa in Kersa of intermediate agro-ecology and until 120 days in Sekoru of low land agro-ecology. Penicillium chrysogenum recorded for Gombisa after 4 months in OmoNada of Intermediate ago-ecology.

Presence of field fungal species like C. cladosporioides and A. flavus on maize stored in Gombisa and Sacks could be due to infestation of standing grain in the field, or from repeated use of the same drying floor year after year. The optimum temperature for growth of stored grain mold is about $25-30^{\circ} \mathrm{C}$, but some species like Aspergillus spp. grow well at $35-37^{\circ} \mathrm{C}$ or above. Grains can be contaminated by spores of storage fungi during harvest, transport and handling operations [31]. A number of fungi isolated in the present study are known to produce mycotoxins which are harmful for 
human health [11, 13]. Mycotoxins can cause severe damage to liver, kidney and nervous systems of human being even in low dosages [3]. Fusarium and Aspergillus species are common fungal contaminants of maize and also produce mycotoxins [4, 32]. A. flavus produces aflatoxins $B_{1}, B_{2}, G_{1}$ and $G_{2}$ which are carcinogenic and produce liver cancer [33-34]. Aflatoxins have powerful tetratogenic, mutagenic and hepato-carcinogenic effects [35]. A. terreus attacks human skin and nail and is parasitic on human ear [36]. F. oxysporum produce Zeralenone $\alpha$ and Zeralenone $\beta$ that cause haemorrhage and necrosis in bone marrow. Other mycotoxins include trichothecenes and zearalenone, compounds known to injure the intestines, bone marrow, lymph nodes, spleen, and thymus. They are produced by species of Fusarium that grow on grain [33]. Besides, species of Penicillium cause kidney disease in human and pigs due to production of the mycotoxin called Citrinin [37].

\section{CONCLUSION}

The current study revealed that fungi such as $A$. flavus, $A$. niger, D. halodes and $F$. oxysporum are the major pathogens of maize stored in traditional storage structures (Gombisa and Sacks) under intermediate and low land agro-ecologies of Jimma zone, Ethiopia. As the storage period increased, the presence of some of the most common fungi pest were consistent, the damage they inflict to stored maize increases in both storage structures and ecologies affecting viability (germination capacity) of the seeds for the next planting season and the usability of the seeds as food and feed because of the potential toxins they may produce. This calls for future research in the area of investigating alternative eco-friendly fungi management methods such as the use of botanicals with fungicidal effects, physical and mechanical methods that modify the suitability of the physical environment for the multiplication of these fungi, identifying resistant and or tolerant maize varieties, identification/screening of effective bio-agents, screening of effective synthetic fungicides with novel chemistry. Furthermore, there is a strong need to train maize producers, traders and consumers who are involved in production and marketing chains of maize crop in the area of storage pests and their effective management. Improved storage structures need to be investigated for maize grain storage in the study area too.

\section{ACKNOWLEDGEMENTS}

Authors acknowledge the financial support of Oromia Agricultural Research Institute (OARI). Authors are also grateful to JUCAVM (Jimma University College of Agriculture and Veterinary Medicine) and JARC (Jimma Agricultural Research Center) for laboratory and logistics support. 


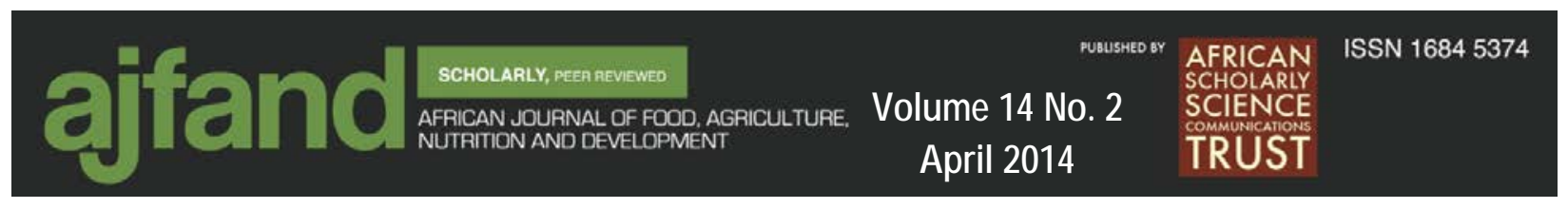

Table 1: Germination percentage of maize grain sampled from Gombisa and Sacks under intermediate and lowland agro-ecologies

\begin{tabular}{|c|c|c|c|c|}
\hline \multirow{3}{*}{$\begin{array}{c}\text { Storage } \\
\text { period (days) }\end{array}$} & \multicolumn{4}{|c|}{ Germination (\%)* } \\
\hline & \multicolumn{2}{|c|}{ Intermediate agro-ecology } & \multicolumn{2}{|c|}{ Lowland agro-ecologies } \\
\hline & Gombisa & Sacks & Gombisa & Sacks \\
\hline Initial loading day & $98.00 \pm 0.52^{\mathrm{a}}$ & $97.50 \pm 0.62^{\mathrm{a}}$ & $97.50 \pm 0.76^{\mathrm{a}}$ & $96.50 \pm 0.76^{\mathrm{a}}$ \\
\hline 60 & $87.50 \pm 1.23^{\mathrm{b}}$ & $92.00 \pm 1.77^{\mathrm{a}}$ & $79.50 \pm 7.29^{b}$ & $86.00 \pm 5.82^{b}$ \\
\hline 120 & $81.33 \pm 4.73^{\mathrm{b}}$ & $80.17 \pm 2.75^{b}$ & $79.17 \pm 4.24^{\mathrm{b}}$ & $83.67 \pm 1.54^{b}$ \\
\hline 180 & $68.50 \pm 2.90^{c}$ & $80.50 \pm 2.01^{b}$ & $70.17 \pm 4.29^{\mathrm{b}}$ & $83.83 \pm 1.85^{\mathrm{b}}$ \\
\hline LSD (0.05) & 10.50 & 11.50 & 18.00 & 10.50 \\
\hline
\end{tabular}

*Means of twelve observations

Means \pm standard error with different letters in a column are significantly different $(\mathrm{p}<0.05)$ according to least significance difference test 


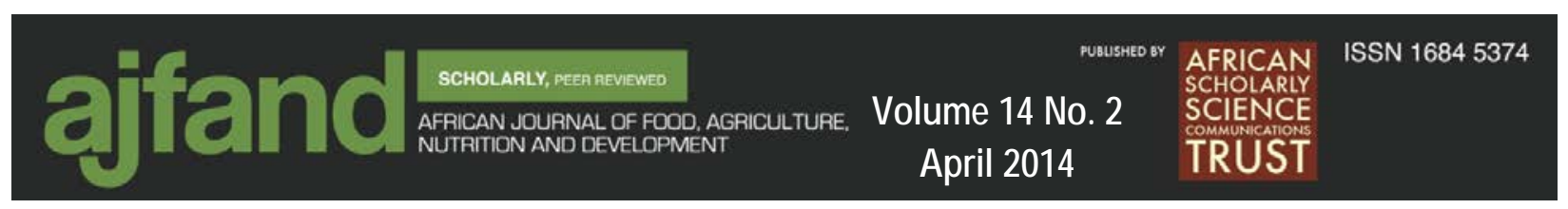

Table 2: Appearance of mycoflora in Kersa and Omo Nada storage containers of intermediate agro-ecology

\begin{tabular}{|c|c|c|c|c|c|c|c|c|c|c|c|c|c|c|c|c|}
\hline \multirow{3}{*}{ Fungi identified } & \multicolumn{8}{|c|}{ Kersa } & \multicolumn{8}{|c|}{ Omo Nada } \\
\hline & \multicolumn{4}{|c|}{ Gombisa } & \multicolumn{4}{|c|}{ Sack } & \multicolumn{4}{|c|}{ Gombisa } & \multicolumn{4}{|c|}{ Sack } \\
\hline & ID & 60 & 120 & 180 & ID & 60 & 120 & 180 & ID & 60 & 120 & 180 & ID & 60 & 120 & 180 \\
\hline Aspergillus flavus & + & + & + & + & + & + & + & + & + & + & + & + & + & + & + & + \\
\hline A. fumigatus & - & - & - & - & - & - & - & - & + & + & - & - & - & - & - & - \\
\hline A. niger & + & + & + & + & + & + & + & + & + & + & + & - & + & + & + & + \\
\hline A. tereus & - & + & - & - & - & - & - & - & - & - & - & - & - & - & - & - \\
\hline $\begin{array}{l}\text { Cladosporium } \\
\text { cladosporioides }\end{array}$ & + & + & - & - & - & - & - & - & - & - & - & - & - & - & - & - \\
\hline Drechslera halodes & + & + & + & + & + & + & + & + & + & + & + & + & + & + & + & + \\
\hline Fusarium oxysporum & + & + & + & + & + & + & + & + & + & + & + & + & + & + & + & + \\
\hline Penicillium chrysogenum & - & - & - & - & - & - & - & - & - & - & + & - & - & - & - & - \\
\hline Sterile mycelium (white) & + & + & + & + & - & - & - & - & + & + & - & - & - & + & + & - \\
\hline
\end{tabular}




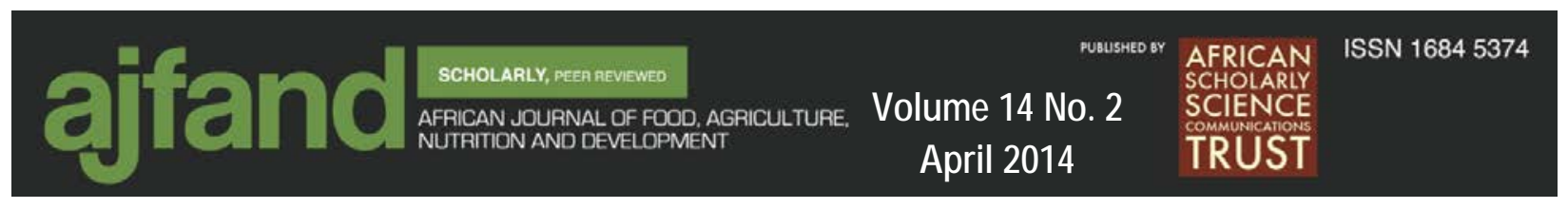

Table 3: Appearance of mycoflora in Sekoru and Tiro Afeta storage containers of lowland agro-ecology

\begin{tabular}{|c|c|c|c|c|c|c|c|c|c|c|c|c|c|c|c|c|}
\hline \multirow{3}{*}{ Fungi identified } & \multicolumn{7}{|c|}{ Sekoru } & \multicolumn{9}{|c|}{ Tiro Afeta } \\
\hline & \multicolumn{3}{|c|}{ Gombisa } & \multicolumn{4}{|c|}{ Sack } & \multicolumn{4}{|c|}{ Gombisa } & \multicolumn{5}{|c|}{ Sack } \\
\hline & ID & 60 & 120 & 180 & ID & 60 & 120 & 180 & ID & 60 & 120 & 180 & ID & 60 & 120 & 180 \\
\hline Aspergillus flavus & + & + & + & + & + & + & + & + & + & + & + & + & + & + & + & + \\
\hline A.fumigatus & + & - & - & - & - & + & - & - & + & - & - & - & - & - & - & - \\
\hline A.niger & + & + & + & - & + & + & + & + & + & + & + & + & + & + & + & + \\
\hline $\begin{array}{l}\text { Cladosporium } \\
\text { cladosporioides }\end{array}$ & + & + & + & - & - & - & - & - & - & + & - & + & - & - & - & - \\
\hline Drechslera halodes & + & + & + & + & + & + & + & + & + & + & + & + & + & + & + & + \\
\hline Fusarium oxysporum & + & + & + & + & + & + & + & + & + & + & + & + & + & + & + & + \\
\hline
\end{tabular}

+ is the presence and - is the absence of fungi; ID, 60, 120 and 180 are storage periods in days; ID = Initial loading day 
Table 4: Percentage occurrence of fungi isolated from stored maize in selected districts of Jimma zone, Ethiopia

Storage periods

$\begin{array}{llllll}\text { Mycoflora } & \text { ID } & 60 & 120 & 180 & \%\end{array}$

\begin{tabular}{lccccc}
\hline Aspergillus flavus & 41 & 46 & 46 & 39 & 90 \\
A.fumigatus & 5 & 2 & 0 & 0 & 3.6 \\
A.niger & 25 & 29 & 25 & 18 & 51 \\
A.tereus & 0 & 1 & 0 & 0 & 0.5
\end{tabular}

Cladosporium

cladosporioides

2

3

2

7

15

Drechslera halodes

33

41

37

27

72

Fusarium oxysporum

16

20

24

24

44

Penicillium chrysogenum

0

0

1

0.5

Sterile mycelium (white)

3

11

3

3

10

'0'indicates the absence of fungi; ID (Initial loading day), 60, 120 and 180 represent storage periods in days 


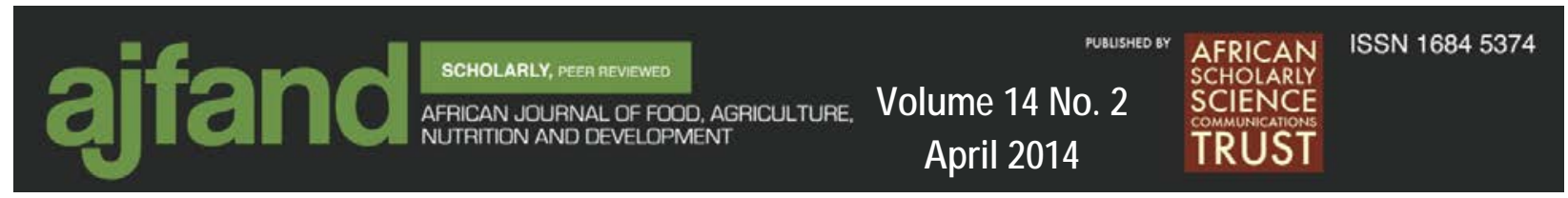

\section{REFERENCES}

1. Girma D, Tadele $\mathbf{T}$ and $\mathbf{T}$ Abraham Importance of husk covering on field infestation of maize by Sitophilus zeamais Motsch (Coleoptera:Curculionidea) at Bako, Western Ethiopia. African Journal of Biotechnology, 2008; 7(20): 3777-3782.

2. CSA (Central Statistical Agency). Agricultural Sample Survey Report on Area and Production of Crops (Private Peasant Holding, Meher Season). Statistical Bulletin, No. 388, Addis Ababa, Ethiopia. 2007.

3. Ishrat $\mathbf{N}$ and $\mathbf{D}$ Shahnaz Detection of seed borne mycoflora in maize (Zea mays L.). Pakistan Journal of Botany, 2009; 41(1): 443-451.

4. Verga BT and $\mathbf{J}$ Teren Mycotoxin producing fungi and mycotoxins in foods in Hungary. Journal of Acta Alimentaria/Akademiai. 2005: 267-275.

5. Ali RH, Mahdi M, Ali RB and S Hojjatollah Mycoflora of maize harvested from Iran and imported maize. Pakistan Journal of Biological Sciences, 2007; 10(24): 4432-4437.

6. Scudamore KA and SJ MacDonald A collaborative study of an HPLC method for determination of ochratoxin-A in wheat using immune-affinity column clean-up. Food Additives Contaminants, 2000; 15: 401-410.

7. Marín S, Sanchis V, Arnau F, Ramos AJ and N Magan Colonisation and competitiveness of Aspergillus and Penicillium species on maize grain in the presence of Fusarium moniliforme and Fusarium proliferatum. International Journal of Food Microbiology. 1998; 45(2): 107-117.

8. Reinaldo BO, Benedito C, Claudia R P, Eliana A S, Jose R N, Silvia MC $\mathbf{D}$ and MAB Malozzi Mycoflora and occurrence of fumonisins in freshly harvested and stored hybrid maize. Journal of Stored Products Research. 2000; 36(1): 75-87.

9. Hussaini AM, Adeniran A.L., Simeon CM, Ifedapo SA, Afeez TM, Uzochukwu JO, Abel SJ, Zakari U and DA Salihu Natural occurrence of ochratoxin A in some marketed Nigerian foods. Food Control. 2013; 31(2): 566-571.

10. Hussaini AM, Michael FD, Patrick BN, Mulunda M and AY Kabiru Natural multi-occurrence of mycotoxins in rice from Niger State, Nigeria. Mycotoxin Research. 2011; 27(2): 97-104.

11. Makun HA, Gbodi TA, Akanya OH, Salako AE and OG Haruna Health implications of toxigenic fungi found in two Nigerian staples: guinea corn and rice. African Journal of Food Science. 2009; 3(9): 250-256. 
12. Samuel TA, Hussaini AM, Titilayo A and I Kudu Effects of Fusarium verticilloides, its metabolites and neem leaf extract on germination and vigour indices of maize (Zea mays L.). African Journal of Biotechnology. 2008; 7 (14): 2402-2406.

13. Makun HA, Dutton MF, Njobeh PB, Gbodi TA and OG Haruna Aflatoxin Contamination in Foods and Feeds: A Special Focus on Africa, Trends in Vital Food and Control Engineering, Prof. Ayman Amer Eissa (Ed.), 2012. ISBN: 978-953-51-0449-0, InTech, Available from: http://www.intechopen.com/books/trends-in-vital-food-and-controlengineering/aflatoxincontamination-in-foods-and-feeds-a-special-focus-onafrica . Accessed on 12/10/2009

14. Fasoyiro S, Yudi W and T Kehinde Processing and Utilization of Legumes in the Tropics, Trends in Vital Food and Control Engineering, Prof. Ayman Amer Eissa (Ed.), 2012. ISBN: 978-953-51-0449-0, InTech, DOI: 10.5772/36496. Available from: http://www.intechopen.com/books/trends-invital-food-and-control-engineering/processing-and-utilization-of-legumes-inthe-tropics. Accessed on 12/10/2009

15. Orsi RB, Corca B and CR Possi Mycoflora and occurrence of fumonisins in freshly harvested and stored hybrid maize. Journal of Stored Products Research, 2000; 36: 75-87.

16. Abebe HG and $\mathbf{H}$ Bekele Farmers' Post-harvest grain management choices under liquidity constraints and impending risks: Implications for achieving food security objectives in Ethiopia. Poster Paper Presented at International Association of Agricultural Economists Conference, Gold Coast, Australia, August 12-8. 2006.

17. Adejumo BA and AO Raji Technical appraisal of grain storage systems in the Nigerian Sudan savannah. Agricultural Engineering International: The CIGR Ejournal. Invited Overview, 2007; 11(9): 1-12.

18. Kemeru D Farm Level Survey on Farm Tools and Implements in Jimma and Iluababor Zones. Agricultural mechanization for productivity and sustainable use of the natural resource. Proceedings of the first agricultural mechanization post harvest and food science research completed research forum, 5-7 June 2007, Addis Ababa, Ethiopia. Pp 171-180.

19. Haile A and T Tolemariam The feed values of indigenous multipurpose trees for sheep in Ethiopia: The case of Vernonia amygdalina, Buddleja polystachya and Maesa lanceolata. Livestock Research for Rural Development, 20(3), Retrieved April 12, 2011, from http://www.Irrd.org/lrrd20/3/hail20045.htm 2008. Accessed on 12/10/2008 
20. FAO (Food and Agriculture Organization of the United Nations), Ethiopia: Agriculture and environment. Rome. http://www.fao.org/ag/AGP/AGPC/doc/Counprof. htm. Accessed on 12/10/2009: 2009.

21. Peter F and A Hampton Small-scale food Processing: A Guide to Appropriate Equipment. IT Publications/ CTA. 1992.

22. AOAC (Association of Official Analytical Chemists) Official Methods of Analysis of Association of Official Analytical Chemists. Association of Official Analytical Chemists, 16 ${ }^{\text {th }}$ edition, Vol. I, INC, Virginia, USA. 1995.

23. Muhammad AA, Akhlaque A, Tasneem A and A Muhammad Use of solar radiation at village level for thermal disinfestation of wheat stored in galvanized steel bins. Pakistan Entomology, 2006; 28 (1): 57-63.

24. ISTA (International Seed Testing Association), International Rules for Seed Testing. Vol. 24, Zurich, Switzerland. 1996.

25. Barnett HL and BB Hunter "Illustrated Genera of Imperfect Fungi." 4th Ed. APS Press, St. Paul, MN. 1998.

26. Ellis MB Demotiaceous Hyphomycetes. C.M.I., Kew Surrey England, 1971: 608.

27. Fekadu L, Geremew B and W Waktola Quality of grain sorghum (Sorghum bicolor (L.) Moench) stored in traditional underground pits: Case studies in two agro-climatic zones in Hararghe, Ethiopia. Journal of Food Science and Technology, 2000; 37(3): 238-244.

28. Rao GS, Hindumathi A, Reddy AN, Kunwar IK and B Bhadraiah Mycoflora associated with seeds of Beta vulgaris var. cicla, Amaranthus tricolor and Portulaca oleracea during storage. J Mycol Plant Pathol . 2011; 41(2):263-267.

29. Peter $\mathbf{F}$ and A Hampton Small-scale food Processing: A Guide to Appropriate Equipment. IT Publications/ CTA. 1992.

30. Shurtleff MC Compendium of Corn Diseases. American Phytopathological Society. St. Paul Minnesota, 1980: 105.

31. Fleurat LF Stored grain: Pest management. In: Wrigley C Corke $\mathbf{H}$ and CE Walker (Eds.) Encyclopedia of Grain Science, 3, Elsevier, UK. 2004: 254263. 
32. Bakan B, Richard D, Molard and B Cahagnier Fungal growth and Fusarium mycotoxin content in isogenic traditional maize and genetically modified maize grown in France and Spain. Journal of Agriculture and Food Chemistry, 2002; 50(4): 278-731.

33. Ammirati JF and MT Seidl "Fungus." Microsoft ${ }^{\circledR}$ Encarta ${ }^{\circledR}$ 2009. (C 19932008 Microsoft Corporation. 2009.

34. Pesta JJ and GS Bonday Alternation of immune function following dietary mycotoxins exposure. Canadian Journal of Physiology and Pharmacology, 1990; 68: 1009-1016.

35. Wang JS and $\mathbf{L}$ Tang Hepatocellular Carcinoma and aflatoxin exposure in Zhyqing village, Fusui County. People's Republic of China Cancer Epidemiology Biomark., 2001; 10: 143-146.

36. Domsch KH, Gams W and T Anderson Compendium of Soil Fungi. Vol. 1. Academic press. 1980: 859.

37. Zuber MS, Lillehoj EB and B L Renfro Aflatoxin in Maize: A proceedings of the workshop. 7-11 April 1986, CIMMYT, El Batan, Mexico. 